ISSN: 2338 - 4794

Vol.6. No. 2 Mei-Agustus 2018

\title{
PENGARUH DISIPLIN KERJA DAN FASILITAS KERJA TERHADAP PRODUKTIVITAS KERJA KARYAWAN MNCTV BAGIAN PRODUKSI
}

\author{
Budi Sayoto ${ }^{1)}$ \\ 1) Mahasiswa Program Studi Manajemen FE UNKRIS \\ Herry Winarto ${ }^{2)}$ \\ 2) Dosen Program Studi Manajemen FE UNKRIS \\ Alamat Kampus UNKRIS, Jatiwaringin Jakarta Timur \\ Email : herrywinarto45@Yahoo.Com
}

\begin{abstract}
This study aims to examine the effect of work discipline and work facilities on employee work productivity, either partially or simultaneously on MNC TV Production Section. The research method used is descriptive and quantitative research method with a sample of 75 respondents. Data collected by using method is multiple linear regression analysis, double correlation and coefficient of determination. Test the hypothesis (Test $F$ and Test $t$ ). The results showed that work discipline and work facilities have a significant effect on increasing productivity of employee of MNC TV Production Division.
\end{abstract}

Keyword : Work discipline, work facilities, and productivity

\section{PENDAHULUAN}

Untuk memenangkan persaingan, perusahaan harus memiliki sumber daya manusia yang berkualitas dan unggul. Sumber daya manusia akan menghasilkan keunggulan bersaing dalam jangka panjang. Hal tersebut dapat terwujud dari adanya peran manajemen sumber daya manusia. Faktor-faktor penting yang sangat berpengaruh terhadap kinerja perusahaan adalah disiplin kerja. Disipilin kerja karyawan sangat diharapkan oleh perusahaan dalam rangka merealisasikan tujuan perusahaan, baik tujuan jangka pendek maupun jangka panjang. Disiplin kerja adalah prosedur yang mengoreksi atau menghukum bawahan karena melanggar peraturan atau prosedur.

Ada beberapa tujuan tindakan disiplin diantaranya adalah : menciptakan bahwa perilaku-perilaku karyawan konsisten dengan aturan-aturan perusahaan, menciptakan atau mempertahankan rasa hormat dan saling percaya diantara pimpinan dan bawahan, membantu karyawan supaya menjadi lebih produktif. Adapun jenis-jenis masalah disiplin karyawan antara lain (Simamora, 2006:) adalah: a). Ketidakhadiran dan keterlambatan; b). Sikap buruk dan tidak loyal; c). Kecerobohan dan kelataan; d). Pembangkangan atasan; e). Perkelahian; f). Pelanggaranpelanggaran peraturan perusahaan; g). Kinerja yang buruk; h). Perlambatan kerja".

Untuk meningkatkan disiplin kerja karyawan, perlu adanya fasilitas kerja yang baik. Menurut Husnan (2008:), "Fasilitas kerja merupakan suatu bentuk pelayanan perusahaan terhadap karyawan agar menunjang kinerja dalam memenuhi kebutuhan karyawan, sehingga dapat meningkatkan produktifitas kerja karyawan". Adanya fasilitas kerja yang disediakan oleh perusahaan sangat mendukung karyawan dalam bekerja. Fasilitas kerja tersebut sebagai alat atau sarana dan prasarana 
untuk membantu karyawan agar lebih mudah menyelesaikan pekerjaannya dan karyawan akan bekerja lebih produktif. Menurut jurnal dengan adanya fasilitas kerja karyawan akan merasa nyaman dalam bekerja dan menimbulkan semangat kerja untuk mendapatkan hasil yang diharapkan oleh perusahaan. Variabel fasilitas kerja dapat dilihat dari adanya fasilitas pendukung seperti : fasilitas ibadah, toilet / WC dan lainlain.Keberhasilan perusahaan juga sangat dipengaruhi oleh produktivitas kerja individu setiap karyawannya. Setiap perusahaan akan selalu berusaha meningkatkan produktivitas kerja karyawan untuk tercapainya tujuan perusahaan. MNCTV adalah salah satu instansi perusahaan jasa yang bertugas dalam bidang jasa.

Dengan mengutamakan jasa melalui peningkatan pengetahuan dan ketrampilan Sumber Daya Manusia dengan perkembangan Ilmu Pengetahuan dan Teknologi (IPTEK), peningkatan jasa menciptakan iklim usaha yang kondusif. Namun demikian, dalam upaya meningkatkan produktivitas kerja karyawan MNCTV, nampaknya masih terdapat banyak hal yang dihadapi sehingga sulit untuk mencapai tujuan organisasi. Kondisi yang belum ideal masih ada di MNCTV. Dimana masih ada kendala lain di MNCTV antara lain disiplin kerja yang belum optimal, fasilitas kerja relatif masih kurang sehingga belum mencapai titik produktivitas yang tinggi.

Produktivitas akan maksimal apabila karyawan yang diberikan beban tugas dilaksanakan dengan sungguhsungguh, tentunya hal ini ditunjang oleh disiplin kerja yang baik, artinya semua aturan yang ada dijalankan/diikuti dengan benar dan fasilitas kerja dilengkapi sesuai dengan kebutuhan kerja.

Anoraga (2009) mengemukakan bahwa produktivitas adalah "menghasilkan lebih banyak, berkualitas lebih baik, dengan usaha yang sama". Dengan demikian produktivitas tenaga kerja adalah efisiensi proses menghasilkan dari sumber daya yang dipergunakan.

Hasibuan (2013) menyatakan : "produktivitas adalah perbandingan antara output (hasil) dengan input (masukan). Jika produktivitas naik ini hanya dimungkinkan oleh adanya peningkatan efisiensi (waktu-bahantenaga) dan sistem kerja, teknik produksi dan adanya peningkatan keterampilan dari tenaga kerjanya".

Dengan kata lain suatu organisasi kerja akan tinggi produktivitasnya dalam segi kuantitas maupun kualitasnya, apabila personal pengelolaannya dari tenaga kerja yang berkualitas / mutu. Di dalam sebuah instansi terdapat berbagai macam sistem sosial yang berkembang dari sekelompok manusia yang saling berinteraksi menurut pola dan tujuan tertentu yang saling mempengaruhi dan dipengaruhi oleh lingkungan nya sehingga membentuk perilaku dari hasil hubungan individu dengan individu maupun dengan lingkungannya. Suasana kerja yang kondusif, kinerja kelompok yang mampu menjaga disiplin kerja dan tersedinaya fasilitas kerja yang mencukupi.

\section{LANDASAN TEORI}

\section{Produktivitas Kerja}

Produktivitas kerja adalah kemampuan yang di miliki karyawan dalam menghasilkan barang atau jasa secara produktif dengan waktu yang singkat dan hasil sesuai dengan yang diharapkan.Produktivitas dapat menjadi tolak ukur dalam melihat suatu keberhasilan yang telah di capai oleh perusahaan atau tempat industri dalam menghasilkan barang atau jasa. Ukuran keberhasilan di nilai dari tingginya produktivitas di bandingkan dengan tingkat produk seperti biasanya 
tergantung juga dengan agregat yang di milikinya.

Menurut Sedarmayanti (2011), Produktivitas merupakan "keinginan dan upaya dari manusia untuk dapat meningkatkan kualitas dalam kehidupannya dan penghidupan di segala aspek bidang". Sedangkan menurut Washin yang diterjemahkan oleh Saksono (2007) mengemukakan bahwa produktivitas di dalamnya mengandung 2 konsep yang utama yaitu "efisien dan efektivitas". "Dalam efisiensi dapat mengukur sumber daya, baik dari manusia, keuangan atau dapat juga dari alam yang dibutuhkan guna memenuhi tingkat dari pelayanan yang diinginkan, efektivitas adalah mengukur dalam segi hasil mutu pelayanan yang telah di capai".

Selanjutnya menurut Ervanto (2005), mengatakan bahwa "produktivitas sebagai rasio antara output dan input, atau rasio antara hasil produk dengan total sumber daya yang digunakan, juga dapat dijabrkan sebagai perbandingan antara hasil kerja dan jam kerja". Kemudian menurut Hasibuan (2013), Produktivitas adalah "perbandingan antara output (hasil) dengan input (masukan), Jika produktivitas naik ini hanya dimungkinkan oleh adanya peningkatan efisiensi (waktu-bahan-tenaga) dan sistem kerja, teknik produksi dan adanya peningkatan ketrampilan dari tenaga kerjanya".

Menurut Ranftl (dalam Salinding,

2011), karakteristik kunci profil karyawan yang produktif. Karakteristik yang dimaksud adalah sebagai berikut : 1). "Lebih dari sekedar memenuhi kualifikasi pekerjaan; kualifikasi pekerjaan dianggap hal yang mendasar, karena produktivitas tinggi tidak mungkin tanpa kualifikasi yang benar. 2). Bermotivasi tinggi; motivasi sebagai faktor kiritis, karyawan yang bermotivasi berada pada jalan produktivitas tinggi. 3).
Mempunyai orientasi pekerjaan posotif; sikap seseorang terhadap tugasnya sangat mempengruhi kinerjanya, faktor positif dikatakan sebagai faktor utama produktivitas karyawan. 4). Dewasa; karyawan yang dewasa memperhatikan kinerja yang konsisten dan hanya memerlukan pengawasan internal. 5). Dapat bergaul dengan efektif; kemampuan untuk menetapkan hubungana antar pribadi yang positif adalah aset yang sangat meningkatkan produktivitas".

\section{Disiplin Kerja}

Kata disiplin itu sendiri berasal dari bahasa latin "discipline" yang berarti "latihan atau pendidikan kesopanan dan kerohanian serta pengembangan tabiat". Hal ini menekankan pada bantuan kepada karyawan untuk mengembangkan sikap yang layak terhadap pekerjaannya. Disiplin merupakan suatu kekuatan yang berkembang di dalam tubuh pekerja sendiri yang menyebabkan dia dapat menyesuaikan diri dengan sukarela kepada keputusan-keputusan, peraturanperaturan, dan nilai-nilai tinggi dari pekerjaan dan tingkah laku (Asmiarsih, 2006).

Menurut Fathoni (2006) kedisiplinan adalah "kesadaran dan kesediaan seseorang menaati semua peraturan perusahaan dan norma-norma sosial yang berlaku". Kedisiplinan dapat diartikan bilamana karyawan selalu datang dan pulang tepat pada waktunya, mengerjakan semua pekerjaannya dengan baik, mematuhi semua peraturan perusahaan dan norma-norma sosial yang berlaku. Kedisiplinan harus ditegakkan dalam suatu organisasi perusahaan, karena tanpa dukungan disiplin karyawan yang baik maka sulit perusahaan untuk mewujudkan tujuannya.

Hasibuan (dalam Barnawi, 2012), disiplin kerja adalah "kemampuan kerja seseorang untuk secara teratur, tekun, terus menerus, dan bekerja sesuai dengan 
aturan-aturan yang berlaku dengan tidak melanggar aturan-aturan yang sudah ditetapkan". Pengertian tentang disiplin telah banyak di definisikan dalam berbagai versi oleh para ahli. Ahli yang satu mempunyai batasan lain apabila dibandingkan dengan ahli lainnya.

$$
\text { Definisi pertama yang }
$$

berhubungan dengan disiplin diantaranya seperti yang dikemukakan oleh Moenir (2014) yaitu "kepatuhan untuk menghormati dan melaksanakan suatu sistem yang mengharuskan orang untuk tunduk pada keputusan, perintah atau peraturan yang berlaku". Dengan kata lain, disiplin adalah kepatuhan mentaati peraturan dan ketentuan yang telah ditetapkan. Berdasarkan pendapatpendapat tersebut, dapat disimpulkan bahwa disiplin kerja karyawan merupakan sikap atau tingkah laku yang menunjukkan kesetiaan dan ketaatan seseorang atau sekelompok orang terhadap peraturan yang telah ditetapkan oleh instansi atau organisasinya baik yang tertulis maupun tidak tertulis sehingga diharapkan pekerjaan yang dilakukan efektif dan efesien.

Indikator yang mempengaruhi tingkat kedisiplinan karyawan suatu perusahaan, diantaranya yang disampaikan oleh Moenir (2014). Indikator - indikator yang mempengaruhi disiplin kerja : 1). Ketepatan waktu; a. Ketepatan waktu dalam melaksanakan tugas. b. Penghematan waktu dalam melaksanakan tugas. 2). Tanggung jawab; a. Melakukan pekerjaan sesuai dengan rencana. b. Mengevaluasi hasil pekerjaan. c. Keberanian menerima resiko kesalahan. 3). Ketaatan. a. Ketaatan terhadap jam kerja. b. Ketaatan terhadap pimpinan. c. Ketaatan terhadap prosedur dan metode kerja.

\section{Fasilitas Kerja}

Fasilitas adalah segala seuatu atau sarana yang dapat mempermudah upaya dan memperlancar serta memudahkan kerja dalam rangka mencapai suatu tujuan. Dapat diartikan pula ialah sarana utama maupun sarana penunjang tempat usaha. Dalam suatu pencapaian tujuan perusahaan, diperlukan alat atau sarana pendukung yang digunakan dalam aktivitas sehari - hari pada perusahaan tersebut. Fasilitas yang digunakan dalam bermacam - macam bentuk, jenis maupun manfaatnya dan di sesuaikan dengan kebutuhan serta kemampuan dari perusahaan. Fasilitas berasal dari bahasa belanda "faciliteit" yang artinya prasarana atau wahana untuk melakukan dan mempermudah sesuatu.

Adapun yang dapat memudahkan dan melancarkan usaha ini dapat berupa benda-benda ataupun uang, dalam hal ini fasilitas disamakan dengan perlengkapan kerja yang ada dalam perusahaan. Fasilitas juga dapat diamggap suatu alat, terdapat banyak faktor yang mendukung suatu perusahaan mencapai tujuannya. Salah satu diantaranya adalah fasilitas kerja bagi karyawan perusahaan dan hal ini merupakan faktor pendukung bagi kelancaran karyawan didalam menjalankan tugas yang mereka kerjakan sehingga hasilnya akan sesuai dengan yang diharapkan perusahaan maupun karyawan tersebut. Fasilitas kerja juga mencangkup lingkungan kerja, dengan adanya lingkungan kerja yang nyaman maka karyawan dapat melaksanakan kegiatan dengan baik dan maksimal.

Fasilitas juga dapat di artikan sebagai sarana dan prasarana yang tersedia di lingkungan, didalam kantor perusahaan atau instansi, dimaksudkan untuk memberikan pelayanan maksimal agar pemirsa merasa nyaman dan puas. Fasilitas merupakan faktor penunjang utama dalam kegiatan suatu produk. Menurut Moekijat (2010) secara sederhana yang dimaksud dengan fasilitas adalah "suatu sarana fisik yang dapat memproses suatu masukkan (input) menuju keluaran (output) yang di 
inginkan". Selanjutnya menurut Buchari Alma (2009) fasilitas ialah "perlengkapan - perlengkapan fisik untuk memberikan kemudahan kepada penggunanya sehingga kebutuhan pengguna fasilitas tersebut dapat terpenuhi". Ditambahkan oleh Barry Cushway (2002) fasilitas kerja adalah "sebagai sarana yang diberikan perusahaan untuk mendukung jalannya nada perusahaan dalam mencapai tujuan yang ditetapkan oleh pemegang kendali". Maka pelayanan yang perusahaan berikan dan bersifat fasilitas kerja merupakan sumber daya fisik perusahaan yang harus ada sebelum suatu jasa ataupun produk ditawarkannya.

Indikator fasilitas kerja menurut Moenir (2014) dari pengertian fasilitas tersebut maka dapat dibagi menjadi tiga golongan besar yaitu: 1). Fasilitas Alat Kerja. 2). Fasilitas Perlengkapan Kerja. 3). Fasilitas Sosial

\section{METODE PENELITIAN}

\section{Variabel dan Pengukuran}

Menurut Sugiyono (2016), variabel penelitian adalah "suatu atribut atau sifat atau nilai dari orang, objek atau kegiatan yang mempunyai variasi tertentu yang ditetapkan oleh peneliti untuk dipelajari dan kemudian ditarik suatu kesimpulan”. Menurut Sugiyono (2016), variabel bebas adalah "variabel yang mempengaruhi atau yang menjadi sebab perubahan atau timbulnya variabel terikat". Sedangkan variabel terikat adalah "variabel yang dipengaruhi atau yang menjadi akibat karena adanya variabel bebas". Pada penelitian ini konsep-konsep variabel yang diteliti ada tiga yaitu disiplin kerja, fasilitas kerja dan produktivitas kerja karyawan.

\section{Instrumen Pengukuran}

Menurut Sugiyono (2016), instrumen penelitian adalah "suatu alat yang digunakan mengukur fenomena alam maupun sosial yang diamati". Secara spesifik fenomena tersebut disebut variabel penelitian. Variabel-variabel penelitian ini akan di ukur oleh instrumen pengukuran dalam bentuk kuesioner yang bersifat tertutup yang memenuhi persyaratan-persyaratan skala likert. Skala likert digunakan untuk mengukur sikap, pendapat, dan persepsi seseorang atau sekelompok orang tentang fenomena sosial.

\section{Populasi Penelitian}

Menurut Sugiyono (2016), populasi adalah "wilayah generalisasi yang terdiri atas: obyek/subyek yang mempunyai kualitas dan karakteristik tertentu yang ditetapkan oleh peneliti untuk dipelajari dan kemudian ditarik kesimpulannya". Sebagai populasi dalam penelitian ini adalah seluruh karyawan Bagian Produk MNCTV yang berjumlah 292 orang.

\section{Sampel Penelitian}

Sampel adalah "bagian dari jumlah dan karakteristik yang dimiliki oleh populasi tersebut". Teknik yang digunakan untuk penarikan sampel adalah simple random sampling. Sugiyono (2016), dikatakan simpel (sederhana) karena pengambilan anggota sampel dari populasi dilakukan secara acak tanpa memperhatikan strata yang ada dalam populasi itu. Penelitian ini menggunakan ukuran sampel dengan rumus Solvin (Umar, 2011). Pada penelitian ini sampel sebagai objek penelitian adalah sejumlah 75 karyawan MNCTV Bagian Produksi berdasarkan simple random sampling (secara acak tanpa memperhatikan strata)

\section{Teknik Pengumpulan Data}

Teknik yang digunakan untuk mengumpulkan data-data dan bahan- 
bahan yang diperlukan yaitu data primer. Data Primer adalah suatu teknik untuk mengumpulkan data dengan menggunakan instrumen pengumpul data, dimana antara pengumpul data dengan responden (sumber data) tidak terjadi wawancara dan tatap muka langsung. Teknik pengumpulan data dilakukan dengan memberikan lembaran pertanyaan (Kuesioner) kepada responden. Teknik ini digunakan untuk memperoleh data primer yang diperlukan sebagai dasar analisis.

\section{HASIL PENELITIAN DAN PEMBAHASAN}

\section{Uji Validitas}

\section{a. Uji Validitas Instrumen Disiplin} Kerja

Dari hasil perhitungan korelasi skor tiap butir pernyataan instrument disiplin kerja dari 75 responden

Tabel 1. Uji Validitas Variabel Disiplin Kerja

\begin{tabular}{cccc}
\hline Kuesioner & R hitung & R kritis & Kesimpulan \\
\hline Instrumen No.1 & 0,482 & 0.30 & Valid \\
Instrumen No.2 & 0,599 & 0.30 & Valid \\
Instrumen No.3 & 0,596 & 0.30 & Valid \\
Instrumen No.4 & 0,643 & 0.30 & Valid \\
Instrumen No.5 & 0,756 & 0.30 & Valid \\
Instrumen No.6 & 0,569 & 0.30 & Valid \\
Instrumen No.7 & 0,633 & 0.30 & Valid \\
Instrumen No.8 & 0,478 & 0.30 & Valid \\
Instrumen No.9 & 0,557 & 0.30 & Valid \\
\hline
\end{tabular}

Sumber : Data diolah tahun 2018

Berdasarkan tabel di atas, dapat dilihat bahwa dari 9 butir pernyataan dari variabel disiplin kerja hasilnya adalah valid.

\section{Uji Instrumen Data Penelitian}

Untuk memperoleh hasil penelitian yang baik maka perlu didukung data yang baik pula. Sedangkan baik tidaknya data tergantung pada instrumen pengumpulan data. Instrumen data yang baik harus memenuhi dua syarat penting yakni valid dan reliabel yaitu dengan menggunakan ujnmi vaiditas dan reliabilitas. dengan jumlah pernyataan masingmasing variabel 9 pernyataan dengan total skor setiap responden diperoleh hasil disajikan dalam tabel sebagai berikut:

\section{b. Uji Validitas Instrumen Fasilitas Kerja}

Dari hasil perhitungan koefisien korelasi skor tiap butir pernyataan instrument fasilitas kerja dari 75 responden dengan jumlah pernyataan masing-masing variabel 9 pernyataan dengan total skor setiap responden hasil disajikan dalam tabel sebagai berikut: 
Tabel 2. Uji Validitas Instrumen Fasilitas Kerja

\begin{tabular}{cccc}
\hline Kuesioner & R hitung & R kritis & Kesimpulan \\
\hline Instrumen No.1 & 0,602 & 0.30 & Valid \\
Instrumen No.2 & 0,696 & 0.30 & Valid \\
Instrumen No.3 & 0,641 & 0.30 & Valid \\
Instrumen No.4 & 0,632 & 0.30 & Valid \\
Instrumen No.5 & 0,540 & 0.30 & Valid \\
Instrumen No.6 & 0,499 & 0.30 & Valid \\
Instrumen No.7 & 0,515 & 0.30 & Valid \\
Instrumen No.8 & 0,452 & 0.30 & Valid \\
Instrumen No.9 & 0,529 & 0.30 & Valid \\
\hline
\end{tabular}

Sumber : Data diolah tahun 2018

Berdasarkan tabel di atas, dapat dilihat bahwa dari 9 butir pernyataan dari variabel disiplin kerja hasilnya adalah valid.

\section{c. Uji Validitas Instrumen Produktivitas Kerja}

Dari hasil perhitungan koefisien korelasi skor tiap butir pernyataan instrument produktivitas kerja dari 75 responden dengan jumlah pernyataan masing - masing variabel 10 pernyataan dengan total skor setiap responden hasil disajikan berikut:

Tabel 3. Uji Validitas Instrumen Produktivitas Kerja

\begin{tabular}{cccc}
\hline Kuesioner & R hitung & R kritis & Kesimpulan \\
\hline Instrumen No.1 & 0,474 & 0.30 & Valid \\
Instrumen No.2 & 0,739 & 0.30 & Valid \\
Instrumen No.3 & 0,663 & 0.30 & Valid \\
Instrumen No.4 & 0,512 & 0.30 & Valid \\
Instrumen No.5 & 0,475 & 0.30 & Valid \\
Instrumen No.6 & 0,514 & 0.30 & Valid \\
Instrumen No.7 & 0,505 & 0.30 & Valid \\
Instrumen No.8 & 0,520 & 0.30 & Valid \\
Instrumen No.9 & 0,650 & 0.30 & Valid \\
Instrumen No.10 & 0,516 & 0.30 & Valid \\
\hline
\end{tabular}

Sumber : Data diolah tahun 2018

Berdasarkan tabel di atas, dapat dilihat bahwa dari 10 butir pernyataan dari variabel produktivitas kerja hasilnya adalah valid.

hasil pengujian berikut diketahui bahwa semua variabel mempunyai alpha di atas 0.60 yang berarti bahwa semua variabel dalam penelitian ini dapat diandalkan.

\section{Uji Reliabilitas}

Selanjutnya dilakukan uji reliabilitas untuk mengetahui sejauh mana hasil pengukurannya dapat diandalkan dan konsisten. Pada tabel 
Tabel 4. Hasil Uji Reliabilitas

\begin{tabular}{lccc}
\hline \multicolumn{1}{c}{ Variabel } & Cronbach Alpha & Nilai kritis $(\boldsymbol{\alpha})=\mathbf{5 \%}$ & Keterangan \\
\hline Disiplin Kerja & 0,770 & 0.60 & Reliabel \\
Fasilitas Kerja & 0,733 & 0.60 & Reliabel \\
Produktivitas Kerja & 0,754 & 0.60 & Reliabel \\
\hline
\end{tabular}

Sumber : Data diolah tahun 2018

Berdasarkan angka-angka reliabilitas cronbach alpha tersebut tampak bahwa seluruh pernyataan yang ada membentuk ukuran yang

\section{Pembahasan}

1. Pengaruh Simultan Disiplin Kerja dan Fasilitaas kerja Terhadap Produktivitas Kerja Karyawan MNCTV Bagian Produksi

Variabel disiplin kerja dan fasilitas
kerja secara simultan mampu

Tabel 5. Model Summary Berganda

\begin{tabular}{lrrrr}
\hline Model & R & R Square & Adjusted R Square & Std. Error of the Estimate \\
\hline 1 & $.898^{\mathrm{a}}$ & .807 & .802 & 1.56925 \\
\hline
\end{tabular}

a. Predictors: (Constant), Fasilitas_Kerja, Disipiln_Kerja

b. Dependent Variable: Produktivitas_Kerja

Tabel 6. Anova

\begin{tabular}{|c|c|c|c|c|c|}
\hline Model & $\begin{array}{l}\text { Sum of } \\
\text { Squares }\end{array}$ & df & Mean Square & $\mathrm{F}$ & Sig. \\
\hline \multirow{3}{*}{1} & 742.697 & 2 & 371.349 & 150.799 & $.000^{\mathrm{b}}$ \\
\hline & 177.303 & 72 & 2.463 & & \\
\hline & 920.000 & 74 & & & \\
\hline
\end{tabular}

a. Dependent Variable: Produktivitas_Kerja

b. Predictors: (Constant), Fasilitas_Kerja, Disipiln_Kerja

Tabel 7. Koefisien Regresi Berganda

\begin{tabular}{|c|c|c|c|c|c|c|}
\hline \multirow{2}{*}{\multicolumn{2}{|c|}{ Model }} & \multicolumn{2}{|c|}{$\begin{array}{c}\text { Unstandardized } \\
\text { Coefficients }\end{array}$} & \multirow{2}{*}{$\begin{array}{c}\text { Standardized } \\
\text { Coefficients } \\
\text { Beta }\end{array}$} & \multirow[t]{2}{*}{$\mathrm{t}$} & \multirow[t]{2}{*}{ Sig. } \\
\hline & & B & Std. Error & & & \\
\hline \multirow{3}{*}{1} & (Constant) & 7.997 & 1.977 & & 4.045 & .000 \\
\hline & Disipiln_Kerja & .747 & .106 & .757 & 7.030 & .000 \\
\hline & Fasilitas_Kerja & .161 & .111 & .157 & 1.458 & .149 \\
\hline
\end{tabular}

a. Dependent Variable: Produktivitas

Dari hasil perhitungan model summary pada tabel di atas, nilai $\mathrm{R}=$ 0,898 dan R Square $=0,807$, sedangkan berdasarkan hasil perhitungan koefisien

regresi secara simultan pada tabel 6 diperoleh persamaan regresi yaitu sebesar $\hat{\mathrm{Y}}=7.997+0,747\left(\mathrm{X}_{1}\right)+0,161\left(\mathrm{X}_{2}\right)$.

Dari persamaan regresi berganda (simultan) dapat dilihat arah hubungan 
yang dihasilkan dari variabel bebas terhadap variabel terikatnya, dengan asumsi variabel lain konstan yaitu: 1). Secara simultan Nilai $r=0,898$, artinya ada hubungan yang signifikan secara simultan antara variabel disiplin kerja dan variabel fasilitas kerja dengan produktivitas kerja karyawan MNCTV Bagian Produksi pada tingkat hubungan yang sangat kuat. 2). Koefisien regresi variabel $\mathrm{X}_{1}$ bertanda positif menunjukkan adanya hubungan yang positif dari variabel disiplin kerja yang menyebabkan kenaikan sebesar 0,747 terhadap produktivitas kerja karyawan. Hal ini menunjukkan dengan adanya disiplin kerja yang baik di MNCTV, produktivitas kerja karyawan dapat meningkat. 3). Koefisien regresi variabel $\mathrm{X}_{2}$ bertanda positif menunjukkan adanya hubungan positif dari variabel fasilitas kerja yang menyebabkan kenaikan sebesar 0,161 terhadap produktivitas kerja karyawan. Hal ini menunjukkan dengan adanya fasilitas kerja yang bagus di MNCTV dapat meningkatkan produktivitas kerja karyawan. 4). Untuk mengukur sejauh mana ketepatan suatu model maka perlu dihitung koefisien determinasinya $\left(\mathrm{R}^{2}\right)$. Koefisien determinasi ini menunjukkan besarnya kemampuan variabel-variabel bebasnya dalam memberikan kontribusi kepada variabel terikatnya. Berdasarkan hasil perhitungan besarnya koefisien determinasi $\left(\mathrm{R}^{2}\right)$ adalah sebesar 0,807 atau $80.7 \%$, hal ini menunjukkan variabel disiplin kerja dan variabel fasilitas kerja dapat memberikan sumbangan terhadap produktivitas kerja karyawan MNCTV Bagian Produksi sebesar 80.7\%, dan sisanya $19.3 \%$ disumbangkan oleh variabel lain yang tidak dijelaskan.

Pengujian hubungan simultan disiplin kerja dan fasilitas kerja terhadap produktivitas kerja karyawan signifikan atau tidak, dilakukan pengujian $\mathrm{F}$ hitung dibandingkan $\mathrm{F}$ tabel atau dengan tingkat Signifikansi $F=0.000$ untuk $\alpha=0.05$.
Berdasarkan perhitungan tersebut di atas pada tabel 7 dapat dinyatakan bahwa Nilai $\mathrm{F}$ hitung $=150.799$ lebih besar dibandingkan dengan $\mathrm{F}$ tabel 3,124 atau tingkat signifikan $=0.000$ jauh lebih kecil dari 0.05 , maka dapat diartikan terdapat pengaruh secara signifikan disiplin kerja dan fasilitas kerja terhadap produktivitas kerja karyawan MNCTV.

Berdasarkan penjelasan di atas menunjukkan bahwa disiplin kerja dan fasilitas kerja mempunyai pengaruh yang positif terhadap produktivitas kerja karyawan, dan disiplin kerja mempunyai pengaruh yang lebih besar daripada variabel lain yaitu fasilitas kerja dalam mempengaruhi produktivitas kerja karyawan, hal ini menunjukkan bahwa disiplin kerja merupakan faktor yang menentukan peningkatan produktivitas kerja karyawan MNCTV Bagian Produksi dibanding dengan fasilitas kerja.

\section{Pengaruh Secara Parsial Disiplin Kerja Terhadap Produktivitas Kerja Karyawan MNCTV Bagian Produksi}

Suatu hal yang menarik untuk dikaji lebih mendalam adalah bagaimana jika dilihat secara parsial, apakah variabel disiplin kerja mampu mempengaruhi tinggi atau rendahnya produktivitas kerja karyawan MNCTV Bagian Produksi. 
Tabel 8. Model Summary Sederhana $\left(\mathbf{X}_{1}\right)$

\begin{tabular}{lrrrr}
\hline Model & R & R Square & Adjusted R Square & Std. Error of the Estimate \\
\hline 1 & $.895^{\mathrm{a}}$ & .802 & .799 & 1.58131 \\
\hline
\end{tabular}

a. Predictors: (Constant), Disipiln_Kerja

Tabel 9. Koefisien Regresi Sederhana $\left(X_{1}\right)$

\begin{tabular}{|c|c|c|c|c|c|}
\hline \multirow[t]{2}{*}{ Model } & \multicolumn{2}{|c|}{$\begin{array}{c}\text { Unstandardized } \\
\text { Coefficients }\end{array}$} & \multirow{2}{*}{$\begin{array}{c}\text { Standardized } \\
\text { Coefficients } \\
\text { Beta }\end{array}$} & \multirow[t]{2}{*}{$\mathrm{t}$} & \multirow[t]{2}{*}{ Sig. } \\
\hline & $\mathrm{B}$ & Std. Error & & & \\
\hline (Constant) & 8.914 & 1.889 & & 4.720 & .000 \\
\hline I Disipiln_Kerja & .883 & .051 & .895 & 17.173 & .000 \\
\hline
\end{tabular}

a. Dependent Variable: Produktivitas_Kerja

Dari hasil perhitungan tabel di atas, model summary nilai $r=0,895$ dan $\mathrm{R}$ Square $=0,802$, sedangkan persamaan regresi parsial pada tabel 8 dapat dilihat arah hubungan yang dihasilkan dari variabel bebas terhadap variabel terikatnya, yaitu: $\hat{y}=8.914+0,883\left(\mathrm{X}_{1}\right)$. 1). Nilai $r=0,895$, artinya ada hubungan yang sangat kuat antara variabel disiplin kerja dengan produktivitas kerja karyawan MNCTV Bagian Produksi pada tingkat hubungan yang sangat kuat. 2). Koefisien regresi variabel $X_{1}$ bertanda positif menunjukkan adanya hubungan positif dari variabel disiplin kerja yang menyebabkan kenaikan sebesar 0,883 terhadap produktivitas kerja Kayawan. Hal ini menunjukkan dengan adanya disiplin kerja yang baik di MNCTV Bagian Produksi, maka produktivitas kerja karyawan akan semakin meningkat. 3). Untuk mengukur sejauh mana ketepatan suatu model maka perlu dihitung koefisien determinasinya $\left(\mathrm{R}^{2}\right)$. Koefisien determinasi ini menunjukkan besarnya kemampuan variabel bebasnya dalam memberikan kontribusi kepada variabel terikatnya. Berdasarkan hasil perhitungan besarnya koefisien determinasi $\left(\mathrm{R}^{2}\right)$ adalah sebesar 0,802 atau $80.2 \%$, hal ini menunjukkan variabel disiplin kerja dapat memberikan sumbangan sebesar $80.2 \%$ kepada variabel produktivitas kerja karyawan sisa sebesar $19.8 \%$ disumbangkan oleh faktor lain yang tidak dijelaskan. 5). Dan untuk menguji hubungan parsial variabel disiplin kerja terhadap produktivitas kerja karyawan signifikan atau tidak, dilakukan pengujian $\mathrm{t}$ hitung dibandingkan dengan $\mathrm{t}$ tabel dengan tingkat kepercayaan $(\alpha)=$ 0.05 , hasilnya adalah $t$ tabel $=1.993$ yang dilihat dari tabel distribusi $t$ (derajat kebebasan $=n-2 ;(75-2=73)$, dengan uji dua pihak). Berdasarkan perhitungan tersebut di atas dapat dinyatakan bahwa nilai $\mathrm{t}$ hitung $=17.173$ dibandingkan dengan $\mathrm{t}$ tabel 1.993 atau $\mathrm{t}$ hitung $>\mathrm{t}$ tabel $(17.173>1.993)$, maka dapat diartikan terdapat pengaruh yang signifikan disiplin kerja terhadap produktivitas kerja karyawan MNCTV Bagian Produksi.

\section{Pengaruh Secara Parsial Fasilitas kerja Terhadap Produktivitas Kerja Karyawan MNCTV Bagian Produksi}

Selanjutnya akan dikaji lebih mendalam adalah bagaimana jika dilihat secara parsial, apakah variabel fasilitas kerja mampu mempengaruhi tinggi atau rendahnya produktivitas kerja karyawan MNCTV Bagian Produksi. 
Tabel 10. Model Summary Sederhana $\left(\mathbf{X}_{2}\right)$

\begin{tabular}{|c|c|c|c|c|c|c|}
\hline Model & $\mathrm{R}$ & R Square & Adjusted R Sc & uare & Error of $t$ & Estimate \\
\hline 1 & $.822^{\mathrm{a}}$ & .675 & & .671 & & 2.0238 \\
\hline a. Predi & s: (Co & $\begin{array}{r}\text { stant), Fasilite } \\
\text { Tabel } 11\end{array}$ & $\begin{array}{l}\text { as_Kerja } \\
\text {. Koefisien } \mathbf{R}\end{array}$ & gresi Sederha & $\mathbf{a}\left(\mathrm{X}_{2}\right)$ & \\
\hline & & & Coefficien & & & \\
\hline Mod & & $\begin{array}{r}\text { Unst } \\
\mathrm{Co}\end{array}$ & $\begin{array}{l}\text { andardized } \\
\text { efficients }\end{array}$ & $\begin{array}{l}\text { Standardized } \\
\text { Coefficients }\end{array}$ & $\mathrm{t}$ & Sig. \\
\hline & & $\mathrm{B}$ & Std. Error & Beta & & \\
\hline 1 & nstant) & 10.417 & 2.511 & & 4.149 & .000 \\
\hline & litas_I & Eerja & .068 & .822 & 12.313 & - .000 \\
\hline
\end{tabular}

a. Dependent Variable: Produktivitas_Kerja

Dari hasil perhitungan model summary pada tabel di atas, nilai $\mathrm{r}=$ 0,822 dan R Square $=0,675$ sedangkan persamaan regresi dapat dilihat pada tabel 10 arah hubungan yang dihasilkan dari variabel bebas terhadap variabel terikatnya, yaitu: $\hat{\mathrm{y}}=10.417+0,843$ $\left(\mathrm{X}_{2}\right)$. Artinya adalah 1). Nilai $\mathrm{r}=0,822$, artinya ada hubungan yang sangat kuat antara variabel fasilitas kerja dengan produktivitas kerja karyawan MNCTV Bagian Produksi pada tingkat hubungan yang sangat kuat. 2). Koefisien regresi variabel $\mathrm{X}_{2}$ bertanda positif menunjukkan adanya hubungan positif dari variabel fasilitas kerja yang menyebabkan kenaikan sebesar 0,843 terhadap produktivitas kerja karyawan. Hal ini menunjukkan dengan adanya fasilitas kerja yang baik pada MNCTV, produktivitas kerja karyawan akan meningkat. 3). Untuk mengukur sejauh mana ketepatan suatu model maka perlu dihitung koefisien determinasinya $\left(\mathrm{R}^{2}\right)$. Koefisien determinasi ini menunjukkan besarnya kemampuan variabel bebasnya dalam mempengaruhi variabel terikatnya. Berdasarkan hasil perhitungan besarnya koefisien determinasi $\left(\mathrm{R}^{2}\right)$ adalah sebesar 0,675 atau $67.5 \%$, hal ini menunjukkan variabel fasilitas kerja dapat memberikan sumbangan sebesar $67.5 \%$ kepada variabel produktivitas kerja karyawan sisa sebesar $32.5 \%$ disumbangkan oleh faktor lain yang tidak dijelaskan. 5). Dan untuk menguji hubungan secara parsial variabel fasilitas kerja terhadap produktivitas kerja karyawan signifikan atau tidak, dilakukan pengujian $\mathrm{t}$ hitung dibandingkan dengan $t$ tabel dengan tingkat $\alpha=0,05$, hasilnya adalah $\mathrm{t}$ tabel $=$ 1,993 yang dilihat dari tabel distribusi $\mathrm{t}$ (derajat kebebasan $=n-2 ;(75-2=73)$, dengan uji dua pihak). Berdasarkan perhitungan tersebut di atas dapat dinyatakan bahwa Nilai $\mathrm{t}$ hitung $=12.313$ dan $\mathrm{t}$ tabel $=1.993$ atau $\mathrm{t}$ hitung $>\mathrm{t}$ tabel $(12.313>1,993)$, maka dapat diartikan terdapat pengaruh yang signifikan variabel fasilitas kerja terhadap produktivitas kerja karyawan MNCTV Bagian Produksi.

Dari hasil penelitian menyatakan bahwa adanya peningkatan disiplin kerja diduga akan meningkatkan produktivitas kerja karyawan MNCTV Bagian Produksi. Hal ini dikarenakan pernyataan bahwa dalam bekerja karyawan dapat mempergunakan waktu semaksimal mungkin, tugas yang diberikan diselesaikan tepat waktu, dalam bekerja melaksanakan tugasnya dengan penghematan waktu, melakukan pekerjaan sesuai dengan rencana, mengevaluasi semua hasil kerja, berani menerima resiko atas kesalahan, taat terhadap jam kerja yang telah ditetapkan, taat terhadap perintah pimpinan, taat terhadap prosedur dan metode kerja yang ditentukan. 
Dari hasil penelitian menyatakan bahwa adanya peningkatan fasilitas kerja diduga akan meningkatkan produktivitas kerja karyawan MNCTV Bagian Produksi. Hal ini dikarenakan pernyataan bahwa manajemen menjalankan kewenangan dan kekuasaan berdasarkan aturan, alat kerja dalam ruangan dapat menunjang pekerjaan, semua fasilitas kerja dilapangan terpenuhi, sarana didalam gedung sudah tersedia, perlengkapan kerja dilapangan sudah sesuai dengan kondisi kerja yang ada, alat-alat yang berfungsi membantu kelancaran tugas sudah ada, terdapatnya tempat beribadah, disiapkan mess bagi karyawan yang bekerja hingga larut malam dan adanya kendaraan dinas bagi karyawan.

\section{KESIMPULAN DAN SARAN}

\section{Kesimpulan}

Berdasarkan pembahasan tersebut maka dapat disimpulkan sebagai beriut: 1). Variabel Bebas secara bersama-sama disiplin kerja dan fasilitas kerja berpengaruh positif dan signifikan terhadap variabel terikat produktivitas kerja karyawan 2). Variabel disiplin kerja berpengaruh positif dan signifikan secara parsial terhadap variabel terikat produktivitas kerja karyawan 3). Variabel fasilitas kerja berpengaruh positif dan signifikan secara parsial terhadap variabel terikat produktivitas kerja karyawan.

\section{Saran}

Saran yang dapat disampaikan pada perusahaan adalah 1). Dari hasil penelitian ini menunjukkan bahwa disiplin kerja dan fasilitas kerja memiliki pengaruh dan hubungan yang sangat kuat terhadap produktivitas kerja karyawan. Untuk itu perusahaan perlu meningkatkan dan mempertahankan disiplin kerja yang sudah baik tersebut, ini dapat dilakukan dengan berbagai cara diantara pimpinan memberikan motivasi kerja yang intensif dan juga memberikan tambahan berupa bonus, insentif, premi dan lain-lain serta berikan fasilitas kerja yang lebih baik dan nyaman sehingga karyawan akan lebih nikmat dalam menjalankan pekerjaannya. 2). Terkait dengan tugas atau pekerjaan yang dilaksanakan oleh para karyawan, pimpinan juga perlu melihat langsung kelapangan kinerja para karyawnnya sehingga pimpinan akan tau secara pasti yang ada didalam pekerjaan, dan pimpinan dapat mengambil suatu kebijksanaan berdasarkan yang terjadi dalam pelaksanaan pekerjaan. Hal ini sangat penting karena pimpinan mengetahui dengan sebenarnya apakah target pekerjaan sesuai dengan harapan yang diinginkan oleh perusahaan.

\section{DAFTAR PUSTAKA}

Aditya Purnayuda. 2012. Pengaruh Disiplin Kerja dan Fasilitas Kerja Terhadap Produktivitas Kerja Karyawan Pada PT. Indatex Palur. Karanganyar. Skripsi : Fakultas Ekonomi Universitas Muhammadiyah Surakarta.

Anoraga, Pandji. 2009. Manajemen Bisnis. Jakarta: Penerbit PT. Rineka Cipta.

Asmiarsih, T. 2006. "Pengaruh Pengawasan Terhadap Disiplin Kerja Pegawai Badan Kepegawaian Daerah Kabupaten Brebes." Skripsi, Fakultas Ilmu Sosial, Universitas Negeri Semarang.

Assauri, Sofjan. 2002. Manajemen Pemasaran: Dasar, Konsep dan Strategi. Jakarta. Rajawali Pers.

Barnawi, dan Mohammad Arifin. 2012. Etika dan Profesi Kependidikan. Yogyakarta: Ar-Ruzz Media.

Barry, Cushway. 2002. Human Resouerce Management. Jakarta. Penerbit PT. Elex Media Kumputindo. 
Buchari, Alma. 2009. Manajemen Pemasaran dan Pemasaran Jasa. Cetakan Kedelapan. Bandung. Penerbit Alfabeta.

Budiyono. 2008. Pengaruh Disiplin Kerja dan Fasilitas Kerja Tearhadap Produktivitas Kerja Karyawan Pada PT. Karya Gemilang Surakarta. Skripsi: Fakultas Ekonomi Universitas Muhammadiyah Surakarata.

Fathoni, Abdurrahmat. 2006. Organisasi dan Manajemen Sumber Daya Manusia. Jakarta: Penerbit PT. Rineka Cipta.

Ghozali, Imam. 2016. Aplikasi Analisis Multivariete: Dengan Program IBM SPSS 23. Semarang: Badan Penerbit Universitas Diponegoro.

Hasibuan, Malayu S. P. 2013. Manajemen Sumber Daya Manusia. Jakarta: Penerbit PT. Bumi Aksara.

Heidjrachman, Ranupandojo dan Suad Husnan. 2008. Manajemen Personalia, Edisi 4. Yogyakarta: Penerbit BPFE Yogyakarta.

Moekijat. 2010. Manajemen Sumber Daya Manusia. Bandung: Penerbit CV. Mandar Maju.

Moenir, H.A.S. 2014. Manajemen Pelayanan Umum di Indonesia. Jakarta: Bumi Aksara.

Nisfiannor, Muhammad. 2009. Pendekatan Statistika Modern untuk Ilmu Sosial. Jakarta: Penerbit Salemba Humanika.

Noor, Juliansyah. 2014. Analisis Data Penelitian Ekonomi \& Manajemen. Jakarta: Penerbit PT Gramedia Widia Sarana Indonesia.

Riduwan \& Sunarto. 2011. Pengantar Statistika untuk Penelitian : Pendidikan, Sosial, Komunikasi, Ekonomi dan Bisnis. Bandung: Penerbit Alfabeta.

Rufik Arofah. 2015. Pengaruh Fasilitas Kantor, Motivasi Kerja dan Disiplin Kerja Terhadap Kinerja Perangkat Desa Di Kecamatan
Tulis Kabupaten Batang. Skripsi: Fakultas Ekonomi Universitas Negeri Semarang.

Saksono, Slamet. 2007. Administrasi Kepegawaian. Yogyakarta: Penerbit Kanisius.

Salinding, Rony. 2011. “Analisis Pengaruh Pelatihan Terhadap Produktivitas Kerja Karyawan Pada PT. Erajaya Swasembada Cabang Makassar." Jurnal Manajemen, Vol.8, No. 1, Hal 83-106.

Santoso, Singgih. 2010. Statistik Multivariat dengan SPSS. Jakarta: Penerbit PT. Elex Media Komputindo.

Saydam, Gouzali. 2006. Manajemen Sumber Daya Manusia: Suatu Pendekatan Mikro. Jakarta: Penerbit Djambaran.

Sedarmayanti. 2011. Manajemen Sumber Daya Manusia: Reformasi Birokrasi dan Manajemen Pegawai Negeri Sipil. Bandung: PT Refika. Aditama.

Simamora, Henry. 2006. Manajemen Sumber Daya Manusia. Edisi Ketiga. Yogyakarta. Penerbit STIEYKPN

Singodimedjo, Markum. 2002. Manajemen Sumber Daya Manusia. Surabaya: Penerbit SMMAS.

Sinungan, Muchdarsyah. 2005. Produktivitas : Apa dan Bagaimana. Jakarta: Penerbit Bumi Aksara.

Sugiyono. 2016. Statikstika Untuk Penelitian. Bandung: Penerbit Alfabeta.

Terry, George R. 2006. Prinsip - Prinsip Manajemen. Jakarta: Penerbit Bumi Aksara.

Tohardi, Ahmad. 2002. Pemahaman Praktis Manajemen Sumber Daya Manusia. Bandung: Universitas Tanjung Pura, Mandar Maju.

Umar, Husein. 2011. Metode Penelitian Untuk Skripsi dan Tesis Bisnis, 
Edisi 2. Jakarta: PT. Raja Grafindo Persada.
Wulfram I, Ervianto. 2005. Manajemen Proyek Kontruksi. Yogyakarta. Penerbit Andi Offset 